\title{
Genotype $x$ environment interaction and stability analysis in lentil (Lens culinaris Medik.)
}

\author{
N.K. Yadav ${ }^{1,2}$, S.K. Ghimire ${ }^{2}$, B. P. Sah ${ }^{1}$, A. Sarker ${ }^{3}$, S.M. Shrestha ${ }^{2}$, S.K. Sah ${ }^{2}$ \\ ${ }^{1}$ Nepal Agricultural Research Council (NARC), Nepal \\ ${ }^{2}$ Institute of Agriculture and Animal Sciences (IAAS), Nepal \\ ${ }^{3}$ International Centre for Agricultural Research in Dry Areas (ICARDA),Nepal
}

\begin{abstract}
Genotype $x$ environment interaction was evaluated under eight environments during lentil growing season of 2013/14 and 2014/15 for grain yield and their component characters of twenty one promising genotypes selected from previous trial of lentil. The variances estimated due genotype, environment and genotype $x$ environment interaction were found to be different significantly for all the characters studies indicating distinct nature of genotypes, environments and genotype $x$ environment interactions in phenotypic expression. High estimates of sum of square (SS) for all the traits are expressed by environment. The explained percentage of grain yield by environment, genotype and genotype environment interaction were 54.86, 19.86 and 25.28 respectively. To find out the effects of GEI on grain yield and its attributing characters, the data were subjected to Additive Main effects and Multiplicative Interaction (AMMI) .The results finally indicated that AMMI stability value and AMMI biplot are informative methods to explore stability and adaptation pattern of genotypes in practical plant breeding and in subsequent variety recommendations. In addition, finding mega environments help to identify the most suitable lentil cultivars that can be recommended for areas within the mega-environment in either one or more test locations. The genotype RL39 (1.254 $\mathrm{mt} \mathrm{ha}^{-1}$ ) and LL10071 (1.196 $\mathrm{mt} \mathrm{ha}^{-1}$ ) produced higher grain yield) than all other genotypes over the environments and performed better at most of the places. The genotypes ,F2003-49L, Arun, 39-S-66L, RL-44, and ILL10071 were found to be comparatively stable as their performance were hardly affected by the Gx E interaction and thus would perform well across a wide range of environments. These genotypes produced higher grain yield than all checks.
\end{abstract}

Keywords- AMMI analysis, Biplot ,Lens culinaris, Stability.

\section{INTRODUCTION}

Lentil (Lens culinaris Medik.) is among the first crop domesticated and has become an important food legume crop in the farming and food systems of many countries. It is a diploid ( $2 \mathrm{n}=14$ chromosomes), self-pollinated, high valued annual cool season grain legume crop with a relatively large genome of 4,063 Mpb (Arumuganathan and Earle, 1991).

Globally, lentil ranks sixth in terms of production among the major pulses and constituted $6 \%$ of total dry pulse production. The important lentil-growing countries of the world are India, Canada, Turkey, Bangladesh, Iran, China, Nepal and Syria (Ahlawat, 2012). The total cultivated area in the world is around 4.6 million hectares producing 4.2 million tons of seeds with an average production of 1095 $\mathrm{kg} / \mathrm{ha}$ (FAO, 2010). Lentil ranks first among pulse crops in Nepal. Its area and production in Nepal is 2, 05,939 ha and $2,26,830$ metric ton , respectively with productivity of 1,101 hectare $\mathrm{kg}$ per )MOAD ,2014, Phenotypes are the mixture of genotype (G) , environment (E) components and interactions $(\mathrm{GxE})$ between them .Some environmental variations are predictable e.g., soil type, soil fertility, plant density while some variations are unpredictable e.g., rainfall, temperature, humidity Genotypes respond differently across a range of environments i.e., the relative performance of varieties depends on the environment . Advanced breeding materials must be evaluated in multiple locations for more than one year.Selection and yield testing are the two major phases of varietal development and the later one is highly influenced by the locations and years of testing. The magnitude of $\mathrm{G} \times \mathrm{E}$ interaction and its components has directly depending on the environmental domain of the varieties to be recommended for commercial cultivation.

The main environmental effects (E) and genotype by environment interaction (GEI) have been reported as the most important sources of variation for the measured yield of crops (Dehghani et al., 2006; Yan et al., 2007; Sabaghnia et al., 2008). For this reason, multi-environmental trials (METs) are conducted throughout the world for major crops every year. Although the measured yield is a combined result of the effects of the genotype (G), E and GE 
interaction, only $\mathrm{G}$ and $\mathrm{GE}$ are relevant to cultivar evaluation and mega environment identification. Typically, E explains mostly (80\% or higher) of the total yield variation, while $\mathrm{G}$ and GE are usually small (Yan and Kang, 2003). However, effective interpretation and utilization of MET data in making selection decisions remain a major challenge to researchers. Some important concepts such as mega environment, specific adaptation, and stability all originate from the GE interaction. A significant GE interaction for grain yield can reduce the usefulness of subsequent analysis and limit the feasibility of selecting superior cultivars (Flores et al., 1998).

Development of widely adapted genotypes is the goal of almost all breeding programmes. For this purpose, the genotypes are grown in different environments and their yield stability is estimated before giving any recommendations for variety release. The GxE interaction refers to differential responses of genotypes or cultivars across a range of environments (Kang, 1998; Kang, 2004; Shakoor et al., 2011).A genotype may be considered to be stable if its environment variance is small

Various methods have been introduced in trying to deduce cultivar reaction in different situations. Additive Main Effects and Multiplicative Interaction (AMMI) analysis is one of the popular parametric of multivariate methods to predict adaptation and stability of cultivars. The usefulness of the method to be applied to some different crops has been noted by many researchers (Abay and Bjørnstad, 2009; Alwala et al., 2010; Annicchiarico et al., 2010). Zobel et al., 1988, proposed the name AMMI first time. The AMMI model is a hybrid model involving both additive and multiplicative components of two way data structure which enabled a breeder to get precise prediction on genotypic potentiality and environmental influences on it. AMMI uses ordinary ANOVA to analyze the main effects (additive part) and principal component analysis (PCA) to analyze the non additive residual left over by the ANOVA (Gauche, 1993). Purchase et al., 2000, developed a quantitative stability value to rank genotypes through the AMMI model, named the AMMI Stability Value (ASV).During the analysis of cultivars stability they found a significant correlation between the stability measures ASV with Shukla and Wricke (Wi), and Eberhart and Russel (S2d), while Finlay and Wilkinson (b), and Linn and Binns (Pi) showed limited correspondence with any of the other methods. The developed ASV was considered to be the most appropriate single method of describing the stability of genotypes. The breeders want to develop and select high yield and high stability lines which is highly desirable but some time, high yield but low stability lines which is desirable for specific selection, low yield and low stability (desirable for special breeding purposes, e.g. drought resistance selection) while low yield but high stability is undesirable and no one wants to select such types.

\section{MATERIALS AND METHODS}

The present experiment material comprised of 21 genotypes of lentil including three checks, selected on the basis of yield performance and other characters from the observation nursery conducted at agronomy division Khumaltar during 2011.

The trials were planted at eight environments viz Agronomy Division, Khumalta (Khu14), Regional Agriculture Research Station, Nepalgung (Nep14), Regional Agriculture Research Station, Parwanipu (Par14), and National Grain Legumes Research Program, Rampur (Ram14) during 2013/14 and Agronomy Division, Khumaltar (Khu15),Regional Agriculture Research Station,Nepalgung(Nep15),Regional Agriculture ResearchStation,Parwanipur(Par15), and Jute Research Program Itahari (Itahari15), during 2014/15 representing diverse agro climate of lentil growing area of Nepal and treats as eight environments. The geographical, climatic, and soil features of the experimental sites are given in Table-1. The trials were conducted in a randomized complete block design (RCBD) with three replications. The plot size was of 4 meter length of four rows ( $1 \mathrm{~m}$ wide) of 25 $\mathrm{cm}$ spacing between rows and $5 \mathrm{~cm}$ between plants. Observations were recorded of nine quantitative traits i.e, days to $50 \%$ flowering (DF), days to $90 \%$ maturity (DM), plant height $(\mathrm{PH})$ in $\mathrm{cm}$, number of primary branches $(\mathrm{PB})$, number of pods per plant (PP), number of seeds per pod (SP), 100 seed weight (SW)in gram, biological yield metric ton per hector (BY $\left.\mathrm{mt} \mathrm{ha}^{-1}\right)$, grain yield metric ton/ha (GY $\mathrm{mt} \mathrm{ha}^{-1}$ ) were recorded following IBPGR descriptor, 1985 .Five plants randomly selected from each plot to take the data of yield attributing characters. Grain yield and biological yields were recorded on the plot basis and converted to the metric ton /ha .Fertilizer was applied @ 20:40:20 kg N, P, K /ha. ANOVA and Stability analysis was carried out by using the AMMI model proposed by Zobel et al .,1998 .

\section{RESULTS AND DISCUSSIONS} AMMI analysis of variance

The genotype, environment and genotype $\mathrm{x}$ environment was significant for all the characters studies indicating distinct nature of genotype, environments and genotype $\mathrm{x}$ environment interactions in phenotypic expression. High 
estimate of sum of square (SS) for all the traits are expressed by environment. The explained percentage of sum of square (SS) of grain yield by environment, genotype, and genotype $\mathrm{x}$ environment interaction are $54.86,19.86$ and 25.28 respectively (Table-2)

Environment significantly explained about $54.86 \%$ of the total sum of squares due to treatments. A large yield variation, explained by environments, indicated that the environments were diverse and a major part of variation in grain yield can be resulted from environmental changes .The significances among the environments indicate that these locations can be used as testing stations for different environments while significant differences among genotypes reveals the differential response of genotypes to different environments . GEI significantly explained $25.289 \%$ of the treatments' variation in grain yield. This is in agreement with Karimizadeh, and Mohammadi, 2010., and Akter et al ,2014. The presence of genotypeenvironment interaction (GEI)was clearly demonstrated by the AMMI model, when the interaction was partitioned among the first three interaction principal component axis (IPCA) .IPCA 1 and IPCA 2 are significant, while IPCA 3 is non- significant. IPCA1 explained $26.25 \%$ of the interaction sum of square in $26 \%$ of the Interaction degree of freedom (DF). Similarly, the second principal component axis (IPCA 2) explained a further $22.61 \%$ of the GEI sum of squares at $24 \%$ Interaction degree of freedom which is in agreement of Gauch and Zobel, 1996 , which recommended that the most accurate model for AMMI can be predicted using the first two IPCAs.

\section{Mean yield comparison-}

The mean yields of all the environments are presented in Table-3. Only 11 genotypes have produced grain yield above the grand mean yield, while all the checks produced below the grand mean .The highest mean grain yield of genotypes averaged over environments was produced by RL 39(1.254 $\left.\mathrm{mt} \mathrm{ha}^{-1}\right)$ followed by ILL10071 (1.196 $\left.\mathrm{mt} \mathrm{ha}^{-1}\right)$ and ILL 2373 (1.172 $\left.\mathrm{mt} \mathrm{ha}^{-1}\right)$ and ILL6256 (1.162 $\mathrm{mt} \mathrm{ha}^{-1}$ ) while lowest by Bari masuro-4 (0.736 mt ha $\left.{ }^{-1}\right)$. Different genotypes showed in consistent performance across all environments. The highest environments mean grain yield over genotypes was recorded from Itahari15 (1.580 $\mathrm{mt} \mathrm{ha}^{-1}$ ) followed by Khu14 (1.427 $\mathrm{mt} \mathrm{ha}^{-1}$ ) and Par14 (1.407 mt $\left.\mathrm{ha}^{-1}\right)$, these environments are rich while other environments are poor and produces lower than the averaged grain yield over environments and genotypes (1.013 $\left.\mathrm{mt} \mathrm{ha}^{-1}\right)$.Lowest mean grain yield $\left(0.624 \mathrm{mt} \mathrm{ha}^{-1}\right)$ was produced at Khu15. During 213/14 highest grain yield was produced by RL39 ( $2.260 \mathrm{mt} \mathrm{ha}^{-1}$ ) at Khu14 while it was highest by ILL6256 at Itahari15 during 2014/15.The high yielding genotypes RL
39, RL11,ILL6256 and ILL 2373 are suitable for specific environments.

\section{Stability analysis by AMMI model}

The AMMI Stability Value (ASV) and AMMI stable index are calculated as suggested by Zobel et al, 1998 and Purchase et al.2000., and their ranks are presented in Table 4.The highest mean grain yield of genotypes averaged over environments was produced by RL 39 (1.254 $\mathrm{mt} \mathrm{ha}^{-1}$ ) followed by ILL10071 (1.196 $\left.\mathrm{mt} \mathrm{ha}^{-1}\right)$ and ILL 2373 (1.172 $\mathrm{mt} \mathrm{ha}^{-1}$ ) and ILL6256 (1.162) while lowest by Bari masuro4 (0.736 $\left.\mathrm{mt} \mathrm{ha}^{-1}\right)$. The genotypes which has low stability value (ASV) is said to be stable and the breeder chose the stable genotypes, having grain yield above the mean grand yield. In this experiment genotype F2003-49L ranked 1st in stability followed by Arun ,39-S-66L ,RL-44 and ILL10071 and suitable for all environment but out of that only ILL10071 produced the mean yield above grand mean.

\section{AMMI 1 biplot}

Biplots are graphs where aspects of both genotypes and environments are plotted on the same axes so that inter relationships can be visualized. There are two basic AMMI biplot,the AMMI 1 biplot, where the main effects of grain yield (genotype mean and environment mean) and IPCA1 scores for both genotypes and environments are plotted against each other. On the other hand, the second biplot is AMMI 2 biplot where scores for IPCA1 and IPCA2 are plotted.

In the AMMI 1 biplot, the usual interpretation of biplot is that the displacements along the abscissa indicate differences in main (additive) effects, whereas displacements along the ordinate indicate differences in interaction effects. Genotypes that group together have similar adaptation while environments which group together influences the genotypes in the same way (Kepton, 1984). The graph shows that the genotypes which are in the right side of perpendicular i.e RL-39,ILL10071, ILL2373,ILL6818,ILL10065,ILL6256 produces the higher grain yield than mean value(Figure-1). The above mentioned genotypes are less affected by GxE inter action. The environment Itahari15, Par14 and khu14 produced the higher grain yield than mean $(1.013 \mathrm{~m} / \mathrm{ha})$ and are rich environment. While remaining environment Nep14, Ram14, Khu15, Nep15, Par15 falls in one mega environments. The remaining genotypes and environments produce lower grain yield than mean value. The environments, Ram 14 and Nep14 are closer and genotypes ILL9976, ILL7164, and Simal are more favorable for those locations.

AMMI 2 biplot

The environmental scores are joined to the origin by side lines. Sites with short arrow do not exert strong interactive 
forces. Those with long arrow exert strong interaction. The genotypes close to ordinate expressed general adaptation, whereas the further genotypes depicted more specific adaptation to environments (Ebdon and Gauch, 2002). All the environments khu14, Nep14, Par14, Ram14, Khu15, Nep15, Par14 and IThari15 are connected to the origin Figure 2. The environments Nep14 and Ram14 had short spokes and they do not exert strong interactive forces. The genotypes occurring close together on the plot will tend to have similar yields in all environments, while genotypes far apart may either differ in mean yield or show a different pattern of response over the environments. Hence, the genotypes near the origin are not sensitive to environmental interaction and those distant from the origins are sensitive and have large interaction.In the present study genotype RL39 and RL 11 (Khu14), ILL10065 and RL44 (Nep14), ILL2373 and Shisir (Par14) ILL10071 and RL-44 (Ram14), RL39 and ILL6811 (Khu15),ILL10071 and RL39 (Nep15) ILL10045 and ILL6024(Par15), and ILL6256 and ILL 2373 (Itahari15) are more responsive to the environment given in parenthesis and are specific adopted. The genotypes F200349L, Arun, 39-S-66L, RL-44, and ILL10071 are less affected by the $\mathrm{G} \times \mathrm{E}$ interaction and thus would perform well across a wide range of environments.

\section{CONCLUSION}

Crop yield is a complex trait that is influenced by a number of component characters along with the environment directly or indirectly. AMMI statistical model could be a great tool to select the most suitable and stable high yielding genotypes for specific as well as for diverse environments. In the present study, AMMI model has shown that the largest proportion of the total variation in grain yield was attributed to environments. The genotype RL39 and ILL10071 showed higher grain yield than all other genotypes over all the environments and performed better at most of the places. The genotypes F2003-49L, Arun, 39-S-66L, RL-44, and ILL10071 were hardly affected by the $\mathrm{G} \times \mathrm{E}$ interaction and thus would perform well across a wide range of environments.

Table.1: Geographical, climatic, and soil features of the experimental sites.

\begin{tabular}{|c|c|c|c|c|c|c|c|c|c|c|}
\hline Locations & Year & Latitude & Longitude & $\begin{array}{l}\text { Altitude } \\
\text { (masl) }\end{array}$ & $\begin{array}{c}\text { Soil } \\
\text { type\&pH }\end{array}$ & $\begin{array}{l}\text { Annual } \\
\text { rainfall }\end{array}$ & $\begin{array}{l}\text { Min } \\
\text { temp }\end{array}$ & $\begin{array}{l}\text { Max } \\
\text { temp }\end{array}$ & \multicolumn{2}{|c|}{$\begin{array}{l}\text { Severity of } \\
\text { disease }\end{array}$} \\
\hline & & & & & & & & & SB & FW \\
\hline $\begin{array}{l}\text { Khumaltar } \\
\text { (Khu14) }\end{array}$ & 2014 & $27^{\circ} 03^{\prime} \mathrm{N}$ & $85^{\circ} 35^{\prime} \mathrm{E}$ & 1440 & $\begin{array}{c}\text { Clay loam } \\
5.5-6.5\end{array}$ & 1340 & 0.2 & 29.0 & $\mathrm{~L}$ & $\mathrm{~L}$ \\
\hline $\begin{array}{c}" \\
\text { (Khu15) }\end{array}$ & 2015 & $"$ & $"$ & $"$ & $"$ & 1230 & -0.4 & 28.0 & M & $\mathrm{L}$ \\
\hline $\begin{array}{l}\text { Nepalgunj } \\
\text { (Nep14) }\end{array}$ & 2014 & $28^{\circ} 05^{\prime} \mathrm{N}$ & $81^{\circ} 61^{\prime} \mathrm{E}$ & 181 & $\begin{array}{c}\text { Clay loam, } \\
7.2-7.5\end{array}$ & 1111 & 5.4 & 46 & $\mathrm{~L}$ & $\mathrm{~L}$ \\
\hline $\begin{array}{c}" \\
(\text { Nep15) }\end{array}$ & 2015 & $"$ & $"$ & $"$ & $"$ & 1250 & 7.2 & 42 & M & $\mathrm{L}$ \\
\hline $\begin{array}{l}\text { Parwnipur } \\
\text { (Par14) }\end{array}$ & 2014 & $27^{\circ} 20^{\prime} \mathrm{N}$ & $84^{\circ} 53^{\prime} \mathrm{E}$ & 115 & $\begin{array}{c}\text { Silty loam } \\
6.0-6.2\end{array}$ & 1687 & 5.0 & 38.0 & $\mathrm{~L}$ & $\mathrm{~L}$ \\
\hline $\begin{array}{c}" \\
(\operatorname{Par} 15)\end{array}$ & 2015 & $"$ & $"$ & $"$ & $\begin{array}{c}\text { Silty loam } \\
6.0-6.2\end{array}$ & 1450 & 6.7 & 36 & M & $\mathrm{L}$ \\
\hline $\begin{array}{l}\text { Rampur } \\
\text { (Ram14) }\end{array}$ & 2014 & $27^{\circ} 40^{\prime} \mathrm{N}$ & $84^{\circ} 19^{\prime} \mathrm{E}$ & 228 & $\begin{array}{c}\text { Sandy loam } \\
4.6-5.7\end{array}$ & 1138 & 1.0 & 34 & $\mathrm{~L}$ & $\mathrm{~L}$ \\
\hline $\begin{array}{c}\text { Itahari } \\
\text { (Itahari15) }\end{array}$ & 2015 & $26.66^{\prime} \mathrm{N}$ & $87.28^{\prime} \mathrm{E}$ & 344 & $\begin{array}{c}\text { Clay loam } \\
6.2-7.2\end{array}$ & 1782 & 7.5 & 34.3 & VL & VL \\
\hline
\end{tabular}

$\mathrm{FW}=$ Fusarium wilt,SB= Stemphylium blight, $\mathrm{L}=$ low, $\mathrm{M}=$ medium, $\mathrm{VL}=$ very low 
Table.2: AMMI analysis of variance for different quantitative traits of 21 lentil genotypes across 8 environments.

\begin{tabular}{|c|c|c|c|c|c|c|c|c|c|c|c|}
\hline & & \multicolumn{9}{|c|}{ Mean sum of square } & \multirow[b]{2}{*}{$\begin{array}{c}\text { Explain } \\
\text { ed\% of } \\
\text { GY }\end{array}$} \\
\hline & Df & DF & DM & $\mathrm{PH}$ & NB & PP & SP & $\begin{array}{l}\text { By mt } \\
\text { ha-1 }\end{array}$ & $\begin{array}{c}\text { Gy } \\
\text { mt } \\
\text { ha-1 }\end{array}$ & SW & \\
\hline ENV & 7 & $\begin{array}{c}4285.5 \\
0 * *\end{array}$ & $\begin{array}{c}9345.20 \\
* *\end{array}$ & $\begin{array}{c}4002.50 \\
* *\end{array}$ & $\begin{array}{c}568.04 \\
* *\end{array}$ & $\begin{array}{c}22995.7 \\
0 * *\end{array}$ & $\begin{array}{c}0.52 * \\
*\end{array}$ & $\begin{array}{c}22.29^{*} \\
*\end{array}$ & $\begin{array}{c}9.86^{*} \\
*\end{array}$ & $3.71 * *$ & 54.86 \\
\hline GEN & 20 & $\begin{array}{c}237.90 \\
* *\end{array}$ & $\begin{array}{c}105.10 * \\
*\end{array}$ & $27.70 * *$ & $\begin{array}{c}12.19 * \\
*\end{array}$ & $\begin{array}{c}1643.50 \\
* *\end{array}$ & $\begin{array}{c}0.06^{*} \\
*\end{array}$ & $1.13 * *$ & $\begin{array}{c}0.23 * \\
*\end{array}$ & $0.57 * *$ & 19.86 \\
\hline $\begin{array}{c}\text { ENV:xG } \\
\text { EN }\end{array}$ & 140 & $\begin{array}{c}48.20^{*} \\
*\end{array}$ & $19.30 * *$ & $17.50 * *$ & $8.15^{* *}$ & $\begin{array}{c}741.20^{*} \\
*\end{array}$ & $\begin{array}{c}0.04 * \\
*\end{array}$ & $0.58 * *$ & $\begin{array}{c}0.32 * \\
*\end{array}$ & $0.23 * *$ & 25.28 \\
\hline Error & 320 & 12.50 & 5.70 & 9.60 & 3.88 & 379.80 & 0.02 & 0.34 & 0.050 & 0.06 & \\
\hline PC1 & 26 & $\begin{array}{c}115.44 \\
* *\end{array}$ & $38.57 * *$ & $45.20 * *$ & $\begin{array}{c}25.53 * \\
*\end{array}$ & $\begin{array}{c}1395.02 \\
* *\end{array}$ & $\begin{array}{c}0.07 * \\
*\end{array}$ & $1.01 * *$ & $\begin{array}{c}0.32 * \\
*\end{array}$ & $0.61 * *$ & $\begin{array}{c}26.25 \text { of } \\
\text { GxE }\end{array}$ \\
\hline PC2 & 24 & $\begin{array}{c}80.15^{*} \\
*\end{array}$ & $28.12 * *$ & $20.88 * *$ & $8.77 * *$ & $\begin{array}{c}1135.67 \\
* *\end{array}$ & $\begin{array}{c}0.06 * \\
*\end{array}$ & $0.88 * *$ & $\begin{array}{c}0.30^{*} \\
*\end{array}$ & $0.37 * *$ & $\begin{array}{c}22.61 \text { of } \\
\text { GxE }\end{array}$ \\
\hline PC3 & 22 & $\begin{array}{c}39.22 * \\
*\end{array}$ & $13.16^{* *}$ & $12.62 * *$ & $4.49 * *$ & $\begin{array}{c}814.69 * \\
*\end{array}$ & $\begin{array}{c}0.04 * \\
*\end{array}$ & $0.67 * *$ & $\begin{array}{c}0.18 \mathrm{n} \\
\mathrm{s} \\
\end{array}$ & $0.20 * *$ & \\
\hline & $\begin{array}{c}\text { Mea } \\
\mathrm{n}\end{array}$ & 92.24 & 131.98 & 31.16 & 7.23 & 64.68 & 1.82 & 2.04 & 1.013 & 1.64 & \\
\hline & $\mathrm{Cv} \%$ & 3.83 & 1.80 & 9.93 & 17.22 & 15.13 & 7.82 & 14.59 & 15.01 & 14.72 & \\
\hline
\end{tabular}

Note-**= significant at $1 \%$ level, $*=$ significant at $5 \%$ level, $\mathrm{ns}=$ non-significant.

Table.3: Mean grain yield in $\mathrm{mt} h \mathrm{a}^{-1}$ of 21 genotypes in 8 environments

\begin{tabular}{|l|l|r|r|r|r|r|r|r|r|r|}
\hline & \multicolumn{3}{|c|}{$2013 / 14$} & \multicolumn{4}{|c|}{$2014 / 15$} & \\
\hline En & Genotypes & Khu14 & Nep14 & Par14 & Ram14 & Khu15 & Nep15 & Par15 & Ithari15 & Mean \\
\hline 1 & ILL 10071 & 1.497 & 0.834 & 1.296 & 1.377 & 0.852 & 1.187 & 0.749 & 1.774 & 1.196 \\
\hline 2 & ILL6811 & 1.305 & 0.691 & 1.673 & 1.247 & 1.090 & 0.954 & 0.630 & 1.172 & 1.095 \\
\hline 3 & ILL 10045 & 1.294 & 1.091 & 1.703 & 0.995 & 0.688 & 0.934 & 1.006 & 1.496 & 1.151 \\
\hline 4 & ILL 10065 & 1.385 & 1.231 & 1.313 & 0.827 & 0.938 & 0.975 & 0.546 & 1.421 & 1.080 \\
\hline 5 & RL-44 & 1.467 & 1.166 & 1.120 & 1.245 & 0.622 & 0.612 & 0.511 & 1.318 & 1.008 \\
\hline 6 & RL-39 & 2.260 & 1.042 & 1.521 & 0.985 & 1.000 & 0.963 & 0.917 & 1.344 & 1.254 \\
\hline 7 & ILL 6256 & 1.537 & 1.066 & 1.454 & 1.072 & 0.718 & 0.647 & 0.603 & 2.204 & 1.162 \\
\hline 8 & 39-S-66L & 1.662 & 0.906 & 1.265 & 0.772 & 0.587 & 0.845 & 0.866 & 1.631 & 1.067 \\
\hline 9 & F2003-49L & 1.399 & 0.890 & 1.391 & 0.744 & 0.421 & 0.638 & 0.616 & 1.512 & 0.951 \\
\hline 10 & ILL 2373 & 1.624 & 1.089 & 1.962 & 0.969 & 0.782 & 0.423 & 0.506 & 2.023 & 1.172 \\
\hline 11 & RL-11 & 2.146 & 0.853 & 1.161 & 0.665 & 0.485 & 0.501 & 0.506 & 1.998 & 1.039 \\
\hline 12 & Khajura-1 & 1.830 & 0.958 & 1.281 & 0.951 & 0.655 & 0.528 & 0.664 & 1.490 & 1.045 \\
\hline 13 & ILL 6024 & 1.796 & 0.248 & 1.208 & 0.944 & 0.567 & 0.522 & 0.982 & 1.930 & 1.025 \\
\hline 14 & ILL 8132 & 1.666 & 0.752 & 1.240 & 0.927 & 0.779 & 0.723 & 0.553 & 1.413 & 1.007 \\
\hline 15 & Shishir & 0.964 & 0.902 & 1.992 & 0.681 & 0.543 & 0.293 & 0.757 & 1.451 & 0.948 \\
\hline 16 & ILL 9976 & 1.059 & 1.060 & 1.488 & 0.663 & 0.525 & 0.357 & 0.781 & 1.615 & 0.943 \\
\hline 17 & ILL 6818 & 0.890 & 0.621 & 0.901 & 0.660 & 0.521 & 0.634 & 0.998 & 1.043 & 0.783 \\
\hline 18 & Arun & 1.207 & 0.963 & 1.302 & 0.816 & 0.428 & 0.386 & 0.741 & 1.782 & 0.953 \\
\hline 19 & Sima1(C1) & 1.057 & 0.522 & 1.926 & 0.963 & 0.204 & 0.269 & 0.340 & 1.351 & 0.829 \\
\hline 20 & Bari masuro-4(C2) & 0.988 & 0.481 & 0.930 & 0.704 & 0.261 & 0.318 & 0.403 & 1.802 & 0.736 \\
\hline
\end{tabular}




\begin{tabular}{|l|l|l|l|l|l|l|l|l|l|l|}
\hline 21 & ILL 7164(C3) & 0.936 & 0.327 & 1.420 & 0.865 & 0.443 & 0.545 & 0.613 & 1.403 & 0.819 \\
\hline & Mean & 1.427 & 0.843 & 1.407 & 0.908 & 0.624 & 0.631 & 0.680 & 1.580 & 1.013 \\
\hline
\end{tabular}

Table.4: Mean grain yield ( $m t^{-1} a^{-1}$ ), AMMI stability values (ASV), stability index and ranking orders of the 21genotypes of lentil

\begin{tabular}{|c|c|c|c|c|c|}
\hline Genotypes & Mean GY mt ha-1 & ASV & rASV & YSI & rYSI \\
\hline F2003-49L & 0.951 & 0.029 & 1 & 16 & 15 \\
\hline Arun & 0.953 & 0.239 & 2 & 16 & 14 \\
\hline $39-s-66 L$ & 1.067 & 0.239 & 3 & 11 & 8 \\
\hline RL-44 & 1.008 & 0.247 & 4 & 16 & 12 \\
\hline ILL10071 & 1.196 & 0.272 & 5 & 7 & 2 \\
\hline Bari masura-4(Ch-2) & 0.736 & 0.275 & 6 & 27 & 21 \\
\hline ILL7164 (Check-3) & 0.819 & 0.279 & 7 & 26 & 19 \\
\hline Khajura-1 & 1.045 & 0.280 & 8 & 17 & 9 \\
\hline ILL8132 & 1.007 & 0.292 & 9 & 22 & 13 \\
\hline ILL10065 & 1.080 & 0.307 & 10 & 17 & 7 \\
\hline ILL9976 & 0.943 & 0.324 & 11 & 28 & 17 \\
\hline ILL10045 & 1.151 & 0.339 & 12 & 17 & 5 \\
\hline ILL6256 & 1.163 & 0.358 & 13 & 17 & 4 \\
\hline ILL6024 & 1.025 & 0.450 & 14 & 25 & 11 \\
\hline ILL6818 & 0.784 & 0.462 & 15 & 35 & 20 \\
\hline ILL2373 & 1.172 & 0.478 & 16 & 19 & 3 \\
\hline RL-39 & 1.254 & 0.493 & 17 & 18 & 1 \\
\hline ILL6811 & 1.095 & 0.539 & 18 & 24 & 6 \\
\hline Simal (check-1) & 0.829 & 0.557 & 19 & 37 & 18 \\
\hline Shisir & 0.948 & 0.652 & 20 & 36 & 16 \\
\hline RL-11 & 1.039 & 0.751 & 21 & 31 & 10 \\
\hline
\end{tabular}

Note- ASV=AMMI stability value, rASV=Rank ofAMMI stability value,Ysi=stability index of grain yield,,rysi=rank stability index of grain yield. 


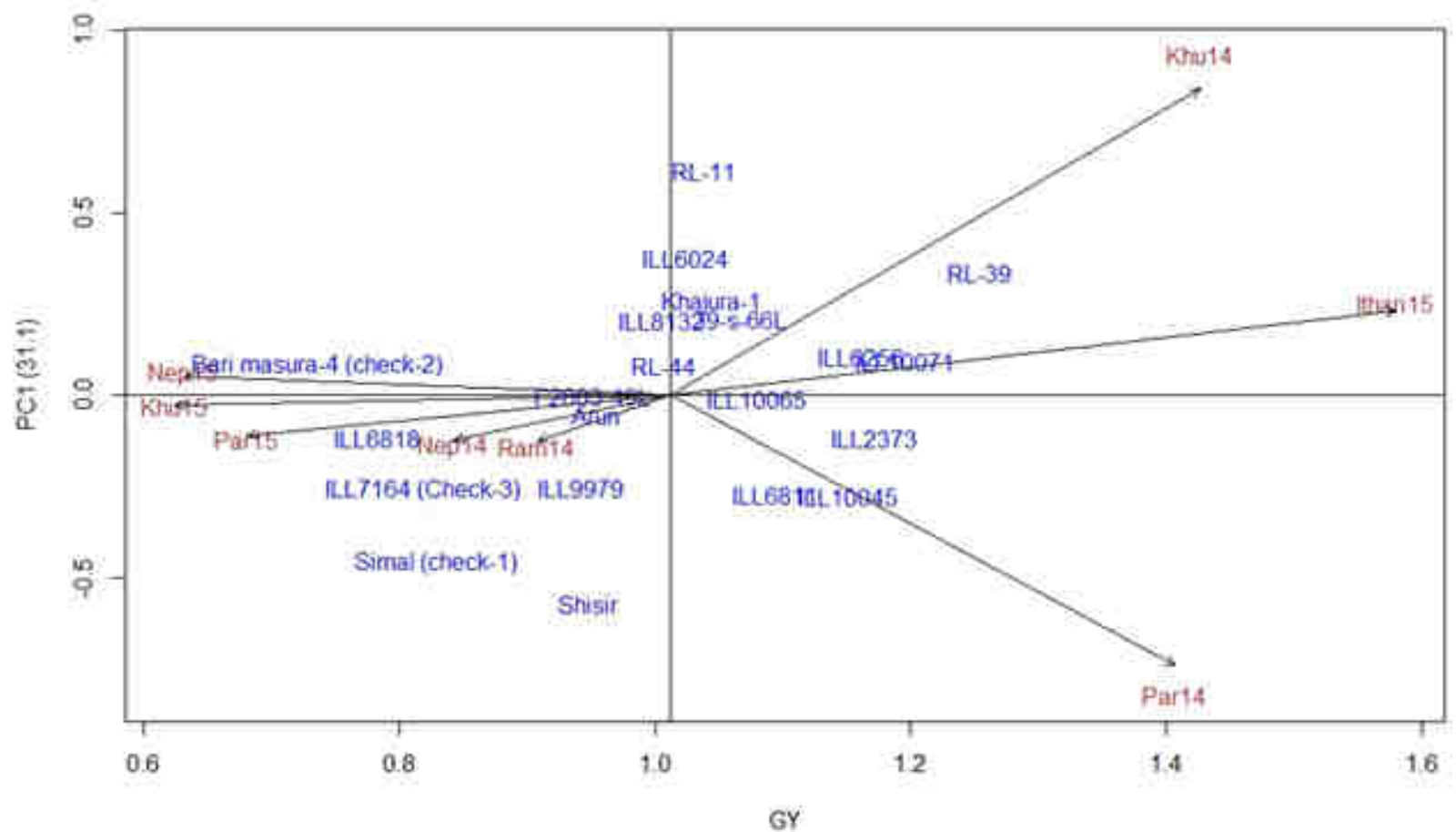

Fig.1: AMMI 1 Biplot for grain yield ( $m$ t ha $\mathrm{a}^{-1}$ ) of 21 lentil genotypes and eight environments using genotypic and environmental scores

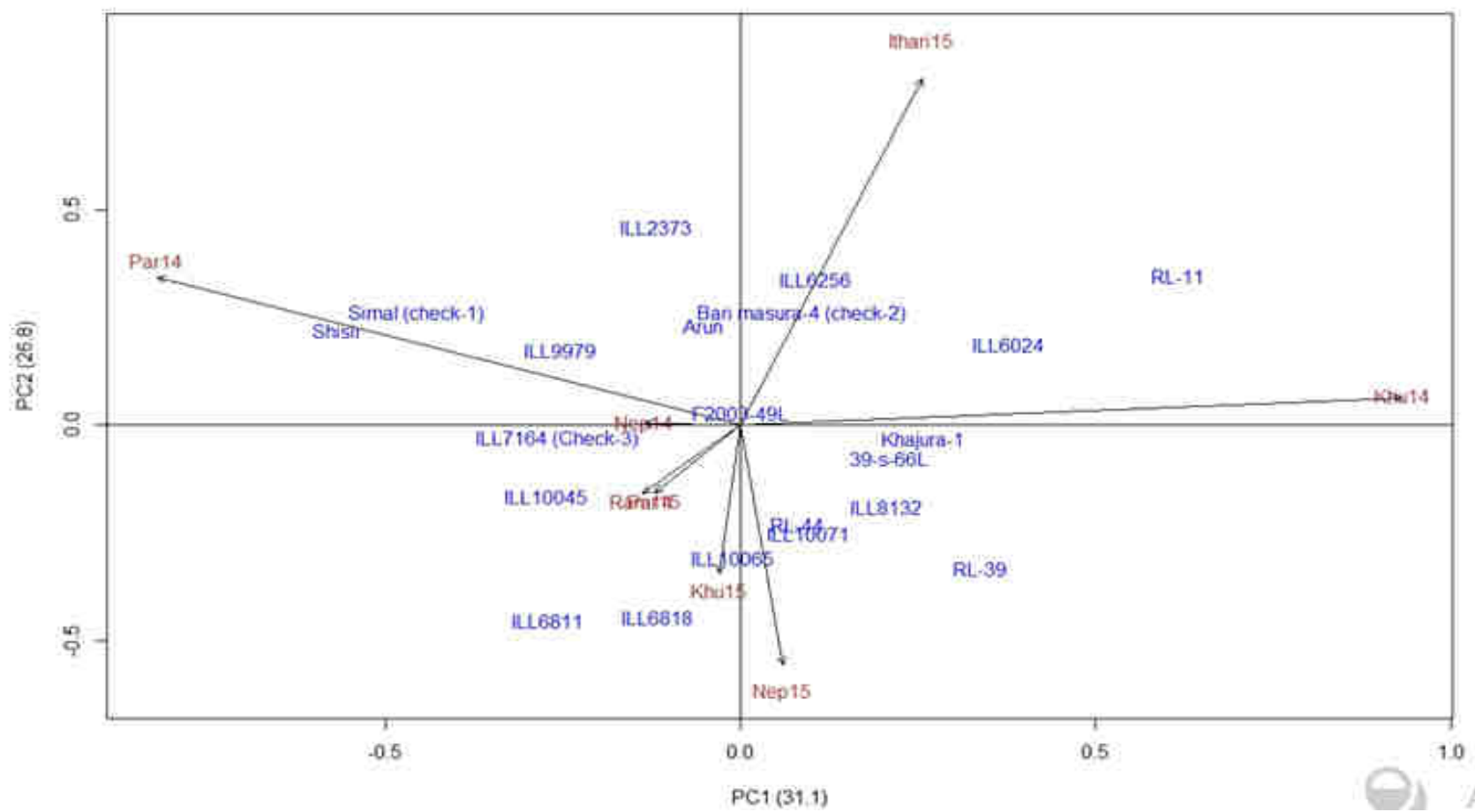

Fig.2: AMMI 2 Biplot for grain yield ( $\mathrm{mt} \mathrm{ha}^{-1}$ ) showing the interaction of IPCA2against IPCA1 scores of 21 lentil genotypes in eight environments.

\section{REFERENCES}

[1] Abay, F. and Bjørnstad A. 2009. Specific Adaptation of Barley Varieties in Different Locations in Ethiopia. Euphytica, 167(2):181-195.

www.ijeab.com
[2] Ahlawat, I. P. S. (2012). Agronomy - rabi crops, Lentil. Division of Agronomy,Indian Agricultural Research Institute, New Delhi - 110012 .

[3] Akter A, Jamil Hassan M, Umma Kulsum M, Islam MR, Hossain K,(2014) AMMI Biplot Analysis for Stability 
of Grain Yield in Hybrid Rice (Oryza sativa )analysis of genotype-by-environment data. Crop Sci., 47: 643-655.

[4] Alwala, S., Kwolek, T., McPherson, M.,Pellow, J. and Meyer, D. 2010. A Comprehensive Comparison between Eberhart and Russell Joint Regression and GGE Biplot Analyses to Identify Stable and High Yielding Maize Hybrids. Field Crops Res., 119: 225230.

[5] Annicchiarico, P., Harzic, N. and Carroni,A. M. 2010. Adaptation, Diversity, and Exploitation of Global White Lupin(Lupinus albus L.) Landrace Genetic Resources. Field Crops Res., 119 (1): 114-124

[6] Arumuganathan K. and E.D. Earle. 1991. Nuclear DNA content of some important plant species. Plant Mol Boil. 9: $208-218$

[7] Dehghani, H., A. Ebadi and A. Yousefi (2006). Biplotanalysis of genotype by environment interactionfor barley yield in Iran. Agron. J., 98:388393.

[8] Ebdon, J. and Gauch, H. 2002. Additive Main Effect and Multiplicative Interaction Analysis of National Turfgrass Performance Trials. I. Interpretation ofbGenotypexEnvironment Interaction. Crop Sci., 42(2): 489-496

[9] Eberhart, S.A. and Russell, W.A. (1966). Stability parameters for comparing varieties. Crop Sci., 6: 36-40.

[10]Eberhart, S.A. and W.A. Russell. 1966. Stability parameters forcomparing varieties. Crop Sci., 6: 36-40.

[11]FAO (2010). FAOSTAT, FAO. Statistical Database. Retrieved from http://www.fao.org

[12] Finlay, KW.andG.N.Wilkinson, 1963. The analysis of adaptation in a plant breeding programme.Aust.j.Agric.Res.14:742-754

[13] Freeman, G.H. 1973. Statistical methods for the analysis of Genotype x Environment Interactions. Heredity, 31(3):339-354.

[14] Gauch HG (1993) Matmodel version 2.0. AMMI and related analysis for two way data matrics. Micro computer power, Ithaca, New York, USA. J., 80:388-39

[15] Gauch HG, Zobel RW (1996) AMMI analysis of yield trials. In M.S. Kang \& H.G. Gauch. (eds.). Genotypeby-environment interaction, pp: 85-122.Gujarat Agric. Uni. Res. J., 22: 101-102.

[16]Kang, M.S. 1998. Using genotype-by-environment interactionfor crop cultivar development. Adv. Agron., 62: 199-252.

[17] Kang, M.S. 2004. Breeding: Genotype-by-environment interaction.In: Encyclopedia of Plant and Crop Science.
(Ed.): R.M.Goodman. Marcel-Dekker, New York, USA. pp. 218-221.

[18] Karimizadeh. R and M. Mohammadi, 2010. AMMI adjustment for rain fed lentil yield trials in Iran. Bulg. J. Agric. Sci., 16: 66-73

[19] Kempton RA (1984) The use of biplots in interpreting variety by environment interactions. Journal of Agricultural Science 103: 123-135.

[20]MOAD,2014. Statistical on Nepalese Agriculture 2013/14.Ministry of Agriculture and Development. buisines promotion and agriculture statistics division,Kathmandu,Nepal

[21] Perkins, J. M. and Jinks, J. L. 1968. Environmental and genotype-environmental components of programme. Australian Journal of Agricultural Research 14(7): 742754.

[22] Purchase JL (1997) Parametric analysis to described G x $\mathrm{E}$ interaction and yield stability in winter yield.Ph.D Thesis. Department of Agronomy, Falculty of Agriculture, University of Orange Free State, Bloemfontein, South Africa. 4-83.

[23] Purchase JL, Hatting H and Van Deventer CS (2000) Genotype $\mathrm{x}$ environment interaction of winter wheat (T.aestivum) in South Africa: Stability analysis of yield performance. S Afr J Plant Soil 17(3):101-107.

[24] Sabghania,N.,.H. Dehghani and S.H.sabaghpour,2006. Non parametric methods for interpreting genotype $\mathrm{x}$ environment interaction of lentil genotypes.Crop science.46:1100-1106

[25] Saravanan, K., M. Gopalan and N. Senthil (1996).Heritability and genetic advance in sunflower.Gujarat Agric. Uni. Res. J., 22: 101-102.

[26] Shakoor, U., A. Saboor, I. Ali and A.Q. Mohsin. 2011. Impactof climate change on agriculture: empirical evidence from arid region. Pak. J. Agri. Sci., 48: 327333 variability. III. Multiple line and crosses.Heredity 23(4): 339-356

[27] Yan, W. and M.S. Kang (2003). GGE-biplot analysis: Agraphical tool for breeders, geneticists, and agronomists. CRC Press, Boca Raton, FL, USA.

[28] Yan, W., M.S. Kang, B. Ma, S. Woods and P.L.Cornelius (2007). GGE Biplot vs. AMMI analysis of genotype-by environment data. Crop Sci., 47: 643655.

[29]Zobel, R. W., Wright, M. J. and Gauch, H.G. 1988. Statistical Analysis of a Yield Trial. Agron.J 80:388393. 